\title{
Pengaruh Budaya Organisasi Terhadap Motivasi Dan Kepuasan Kerja Serta Dampaknya Kepada Kinerja Pegawai Direktorat Jendral Pajak
}

\author{
Sarah Sucia Ramadhani ${ }^{1}$, Eeng Ahman ${ }^{2}$ Syamsul Hadi Senen ${ }^{3}$ \\ Mahasiswa Magister Manajemen Bisnis \\ Sekolah Pasca Sarjana Universitas Pendidikan Indonesia
}

\begin{abstract}
Abstrak
Target penerimaan pajak tahun 2012-2016 belum tercapai. Pencapaian penerimaan pajak Kantor Pelayanan Pajak Pratama Kota Solok pada tahun 2016 menduduki peringkat ke 6 dari 9 kantor yang berada di Kanwil SumbarJa. Fenomena tersebut mengindikasikan masih rendahnya kinerja pegawai. Tinggi rendahnya kinerja pegawai tersebut diprediksi oleh tinggi rendahnya variabel - variabel yang mempengaruhinya, yaitu budaya organisasi,motivasi kerja serta kepuasan kerja. Penelitian ini menggunakan survey dengan jenis verificative explanation reseach terhadap 80 pegawai. Analisis dan interpretasi hasil pengolahan data menggunakan analisis deskriptif dan analisis verifikatif (Partial Least Square). Hasil analisis menunjukan bahwa variabel budaya organisasi dan motivasi kerja termasuk kedalam kategori tinggi sedangkan variabel kepuasan kerja serta kinerja termasuk kategori cukup serta kuat lemahnya budaya organisasi memiliki pengaruh yang positif dan signifikan terhadap tinggi rendahnya motivasi, tinggi rendahnya kepuasan kerja serta tinggi rendahnya kinerja. Tinggi rendahnya motivasi kerja memiliki pengaruh positif dan signifikan terhadap tinggi rendahnya kepuasan kerja dan tinggi rendahnya kinerja. Kemudian tinggi rendahnya kepuasan kerja juga berpengaruh terhadap tinggi rendahnya kinerja pegawai.
\end{abstract}

Kata Kunci: Budaya Organisasi, Motivasi, Kepuasan Kerja, Kinerja, Partial Least Square

\section{PENDAHULUAN}

Perubahan lingkungan yang sangat cepat serta persaingan bisnis yang semakin ketat mengakibatkan organisasi dihadapkan pada tantangan untuk dapat mempertahankan kelangsungan hidup. Keberhasilan sebuah organisasi dipengaruhi oleh kinerja pegawai (employee performance) atau hasil kerja yang di capai oleh seorang pegawai dalam melakukan tugas sesuai dengan tanggung jawab yang diberikan kepadanya. Persoalan yang kemudian muncul adalah bagaimana menghasilkan pegawai yang memiliki kinerja yang optimal. Kinerja pegawai yang optimal merupakan salah satu sasaran organisasi untuk mencapai produktivitas kerja yang tinggi.

Banyak hal yang mempengaruhi kinerja pegawai. Menurut A. Dale Timpe (1992:31) dalam Mangkunegara (2010:15) mengemukakan faktor faktor yang mempengaruhi kinerja dapat dilihat dari faktor internal dan faktor eksternal, yang mana faktor internal adalah faktor yang dihubungkan dengan sifat seseorang. Sedangkan faktor eksternal yaitu faktor faktor yang mempengaruhi kinerja seseorang yang berasal dari lingkungan.

Budaya organisasi selain berpengaruh terhadap kinerja pegawai juga sangat berkaitan erat dengan kepuasan kerja pegawai. Menurut Robbins dan Judge (2015:46) kepuasan kerja merupakan suatu perasaan positif tentang pekerjaan, yang dihasilkan dari suatu evaluasi pada karakteristik - karakteristiknya. Seseorang dengan tingkat kepuasan kerja yang tinggi memiliki perasaan yang positif mengenai pekerjaanya, sedangkan seseorang dengan level yang rendah memiliki perasasan yang negatif. 
Selain budaya organisasi dan kepuasan kerja, variable lain yang berpengaruh terhadap kinerja pegawai adalah motivasi kerja. Menurut Hasibuan (2016:216) motivasi mempersoalkan bagaimana cara mendorong gairah kerja bawahan, agar mereka mau bekerja keras dengan memberikan semua kemampuan dan keterampilannya untuk mewujudkan tujuan perusahaan.

Objek yang digunakan dalam penelitian ini adalah Direktorat Jendral Pajak. Dampak sosial dari pemberitaan kasus mantan petugas pajak Dhana Widyatmika pada tahun 2012 serta Kepala Subdirektorat Handang Soekarno di akhir tahun 2016 sangat merugikan citra Dirjen Pajak yang kini sedang mulai di bangun sejak terjadinya kasus Gayus Tambunan.

Pajak merupakan sumber pendapatan utama negara yang digunakan untuk membiayai pengeluaran negara. Dalam proses mencapai visi misi dan tujuan organisasi banyak strategi yang diterapkan oleh Direktorat Jendral Pajak agar jumlah penerimaan pajak nasional dapat terus meningkat dari tahun ketahun, salah satunya dengan diadakannya program Tax Amnesty yang berjalan hingga 31 Maret 2017.

Pada Gambar 1.1 dapat dilihat bahwa target penerimaan pajak Nasional dari tahun ke tahun selalu bertambah. Hal ini terjadi dikarenakan jumlah anggaran pendapatan dan belanja negara (APBN) yang semenjak 10 tahun terakhir terus naik.

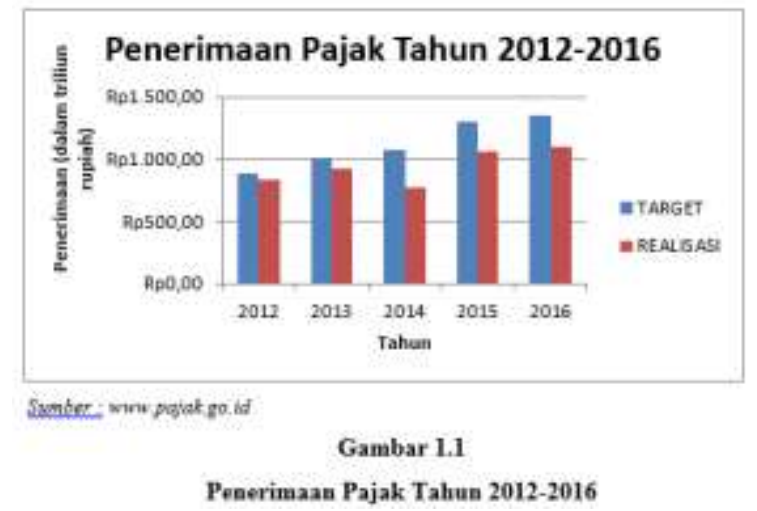

Pada Tabel 1.1 dapat dilihat bahwa salama 5 tahun terakhir (tahun 2012 - tahun 2016) jumlah penerimaan pajak nasional sangat berfluktuasi dari tahun ke tahun. Setiap tahun realisasi jumlah penerimaan pajak memang selalu bertambah. Akan tetapi sangat jauh dari target yang di harapkan.

Tabel 1.1

Penerimaan Pajak Nasional Tahun 2012-2016

\begin{tabular}{|c|c|c|}
\hline TAHUN & PENERIMAAN PAJAK & $\begin{array}{c}\text { JUMLAH } \\
\text { (dalam triliun rupiah) }\end{array}$ \\
\hline \multirow[t]{3}{*}{2012} & TARGET & Rp885.03 \\
\hline & REALISASI & Rp835.26 \\
\hline & PRESENTASE & $94.38 \%$ \\
\hline \multirow[t]{3}{*}{2013} & TARGET & Rp995.21 \\
\hline & REALISASI & Rp916.30 \\
\hline & PRESENTASE & $92.07 \%$ \\
\hline \multirow[t]{3}{*}{2014} & TARGET & Rp1,072.38 \\
\hline & REALISASI & Rp773.34 \\
\hline & PRESENTASE & $72.11 \%$ \\
\hline \multirow[t]{3}{*}{2015} & TARGET & Rp1,294.25 \\
\hline & REALISASI & Rp1,061.24 \\
\hline & PRESENTASE & $82.00 \%$ \\
\hline \multirow[t]{3}{*}{2016} & TARGET & Rp1,355.20 \\
\hline & REALISASI & Rp1,100.61 \\
\hline & PRESENTASE & $81.36 \%$ \\
\hline
\end{tabular}

Pada Tabel 1.2 dapat dilihat bahwa target penerimaan pajak Kantor Pelayanan Pajak Pratama Solok tahun 2016 sebesar Rp 670,75 triliun sedangkan jumlah penerimaannya sebesar Rp 527,344 triliun atau 78.62\% dari target yang telah ditentukan. Artinya sebanyak Rp 143,4 miliyar penerimaan pajak tidak terpenuhi.

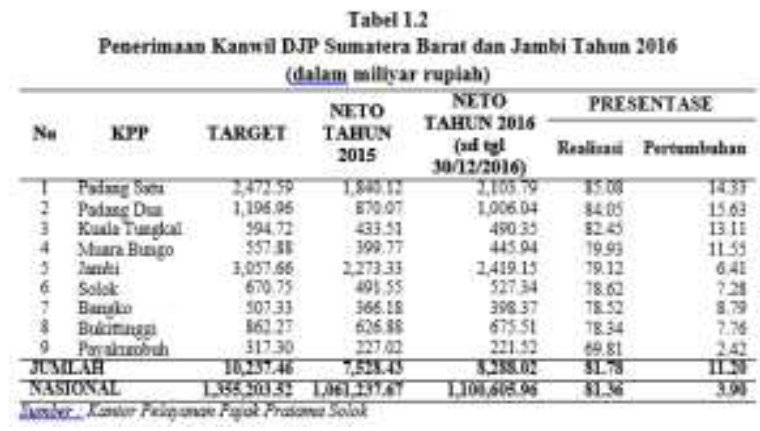

Menempati urutan ke 6 dari 9 kantor pelayanan pajak pratama di Kanwil Sumatra Barat dan Jambi serta belum tercapainya target penerimaan pajak tahun 2016 menjadikan Kantor Pelayanan Pajak Pratama Solok perlu merumuskan kebijakan dalam rangka peningkatan penerimaan pajak pada tahun yang akan datang. Penurunan kinerja perusahaan akan selalu berkaitan dengan kinerja masing - masing pegawai itu sendiri.

Dari permasalahan di atas akhirnya mendorong penulis untuk melakukan penelitian yang berjudul "Pengaruh Budaya Organisasi Terhadap Motivasi dan 
Kepuasan Kerja serta Dampaknya Kepada Kinerja Pegawai Direktorat Jendral Pajak"

\section{KERANGKA PENELITIAN \& HIPOTESIS}

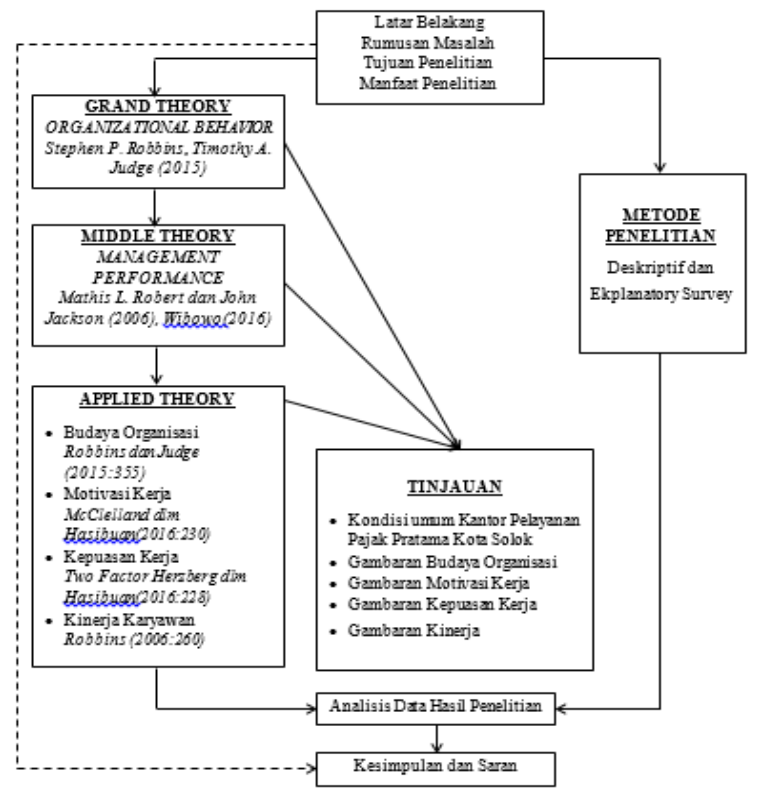

Gambar 2.1

Kerangka Pemikiran

Berdasarkan kerangka pemikiran yang telah dipaparkan, berikut paradigma penelitian mengenai pengaruh variabel budaya organisasi terhadap variabel motivasi dan variabel kepuasan kerja serta dampaknya terhadap variabel kinerja. Dimana variabel budaya organisasi merupakan variabel independen, variabel kepuasan kerja merupakan variabel intervening sedangkan variabel motivasi dan variabel kinerja sebagai variabel dependen. Selanjutnya disajikan model kausalitas variabel penelitian sebagai berikut :

\section{Gambar 2.2}

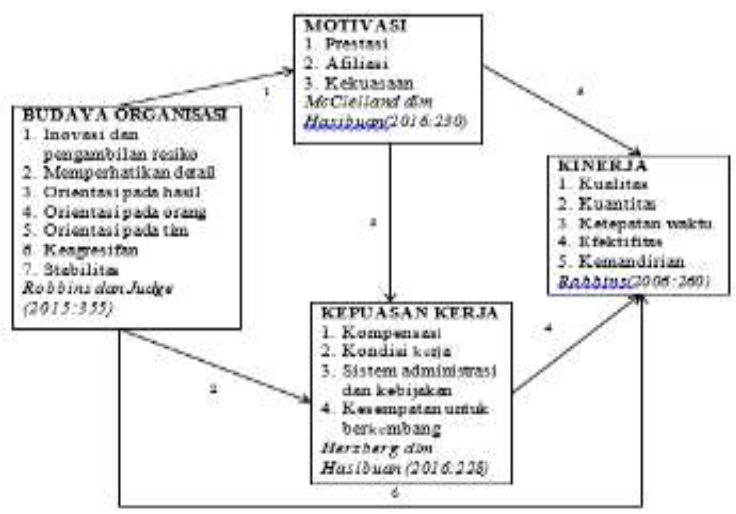

Model Kausalitas Variabel Penelitian
H11: Budaya organisasi berpengaruh terhadap motivasi kerja pegawai pada Kantor Pelayanan Pajak Pratama Solok

H12: Budaya organisasi berpengaruh terhadap kepuasan kerja pegawai pada Kantor Pelayanan Pajak Pratama Solok

H13: Motivasi kerja berpengaruh kepuasan kerja pegawai pada Kantor Pelayanan Pajak Pratama Solok

H14: Kepuasan kerja berpengaruh terhadap kinerja pegawai pada Kantor Pelayanan Pajak Pratama Solok

H15: Motivasi kerja berpengaruh terhadap kinerja pegawai pada Kantor Pelayanan Pajak Pratama Solok

H16: Budaya organisasi berpengaruh terhadap kinerja pegawai pada Kantor Pelayanan Pajak Pratama Solok

\section{METODE PENELITIAN}

Unit analisis dalam penelitian ini adalah pegawai Kantor Pelayanan Pajak Pratama Kota Solok Sumatra Barat. Penelitian ini, terdiri atas empat variabel yang diteliti, yaitu budaya organisasi, motivasi kerja, kepuasan kerja dan kinerja karyawan.

Penelitian ini menggunakan metode survey dengan pendekatannya menggunakan pendekatan kuantitatif. Pada penelitian ini skala yang digunakan adalah skala likert. Penelitian ini akan diuji kebenaran hipotesis melalui pengumpulan data dilapangan.

Jenis data yang digunakan dalam penelitian ini adalah data primer dan data sekunder. Populasi dalam penelitian ini adalah 100 karyawan di Kantor Pelayanan Pajak Pratama Kota Solok. Tekhnik yang digunakan untuk menentukan besarnya ukuran sampel yang diteliti salah satunya dapat menggunakan rumus sampel yang dikemukakan oleh Slovin sehingga responden yang dijadikan sampel dalam penelitian ini adalah pegawai Kantor Pelayanan Pajak Pratama Kota Solok sebanyak 80 responden.

Penelitian ini menggunakan teknik sampel probability dengan penarikan secara simple random sampling 
Metode penelitian memberikan pengetahuan dan keterampilan yang diperlukan untuk mengatasi masalah serta menghadapi tantangan lingkungan di mana pengambilan keputusan harus dilakukan dengan cepat. Keputusan yang diambil akan bersifat lebih ilmiah, jika dilakukan melalui proses penelitian. Seperti yang dikemukakan oleh Sugiyono (2010), menyatakan bahwa: "Metode penelitian pada dasarnya merupakan cara ilmiah untuk mendapatkan data dengan tujuan dan kegunaan tertentu".

Metode penelitian yang digunakan adalah metode penelitian kuantitatif, Seperti yang dikemukakan oleh Sugiyono (2010), menyatakan bahwa: "Metode penelitian kuantitatif sebagai metode penelitian yang berlandaskan pada filsafat positifisme, digunakan untuk meneliti pada populasi atau sampel tertentu, tekhnik pengambilan sampel pada umumnya dilakukan secara random, pengumpulan data menggunakan instrumen penelitian, analisa data bersifat kuantitatif atau statistik dengan tujuan untuk menguji hipotesis yang telah ditetapkan".

Jenis penelitian yang digunakan adalah penelitian deskriptif dan verifikatif.Jenis penelitain deskriptif dipergunakan untuk menggambarkan berbagai gejala dan fakta, serta fenomena yang terdapat dalam kehidupan sosial secara mendalam. Arikunto (2010:3), menyatakan bahawa: "Penelitian deskriptif merupakan penelitan yang benar-benar hanya memaparkan apa yang terdapat atau terjadi dalam sebuah kancah, lapangan, atau wilayah tertentu".

Sedangkan jenis penelitian verifikatif merupakan suatu jenis penelitian yang bertujuan untuk menguji kebenaran hipotesis yang dilakukan melalui pengumpulan data-data di lapangan dengan melakukan uji hipotesis.

Lokasi penelitian yang akan dilakukan adalah di Disnakertrans Provinsi Jawa Barat Jalan Soekarno Hatta No 532 Bandung

Populasi dalam penelitian ini adalah keseluruhan karyawan di kantor Disnakertrans Propinsi Jawa Barat dengan jumlah sebanyak 164 orang karyawan.
Sedangkan sampel dalam penelitian ini yaitu berjumlah 62 orang karyawan

Teknik pengumpulan data yang dilakukan yaitu dengan memberikan angket terutup.

\section{HASIL DAN PEMBAHASAN}

\section{Tabel 4.1}

Hasil Rekapitulasi Pengujian Hipotesis Pengaruh Budaya Organisasi terhadap Motivasi dan Kepuasan Kerja serta dampaknya pada Kinerja Pegawai Kantor Pelayan Pajak Pratama Kota Solok

\begin{tabular}{|c|c|c|c|c|c|}
\hline No & HIPOTESIS & $\begin{array}{l}\text { HIPOTESIS } \\
\text { STATISTIK }\end{array}$ & KEPUTUSAN & $\begin{array}{c}\text { DIRRECT } \\
\text { EFFECT/ } \\
\text { INDIRRECT } \\
\text { EFFECT }\end{array}$ & KESIMPULAN \\
\hline 1 & $\begin{array}{l}\text { BUDAYA } \\
\text { ORGANISASI } \rightarrow \\
\text { MOTIVASI }\end{array}$ & $\begin{array}{l}\text { Ho1: } y_{1}=0 \\
\text { H11: } y_{1} \neq 0\end{array}$ & Ho ditolak & Dirrect effect & $\begin{array}{l}\text { Terdapat pengaruh } \\
\text { gecara langsung } \\
\text { budaya organisasi } \\
\text { terhadap motivasi } \\
\text { kerja pegawai pada } \\
\text { Kantor Pelayanan } \\
\text { Pajak Pratama Solok }\end{array}$ \\
\hline 2 & $\begin{array}{l}\text { BUDAYA } \\
\text { ORGANISASI } \rightarrow \\
\text { KEPUASAN } \\
\text { KERJA }\end{array}$ & Hos: $y_{2}=0$ & Ho ditolak & $\begin{array}{l}\text { Dirrect effect } \\
\text { dan Indirrect } \\
\text { effect }\end{array}$ & $\begin{array}{l}\text { Terdapat pengaruh } \\
\text { gecara langsung } \\
\text { budaya organisasi } \\
\text { terhadap kepuasan } \\
\text { kerja pegawai dan } \\
\text { terdapat pengaruh } \\
\text { secara tidak } \\
\text { langgung budaya } \\
\text { organisasi terhadap } \\
\text { kepuasan kerja yang } \\
\text { dimediasi oleh } \\
\text { motivasi kerja } \\
\text { pegawai pada } \\
\text { Kantor Pelayanan } \\
\text { Pajak Pratama Solok }\end{array}$ \\
\hline 3 & $\begin{array}{l}\text { MOTIVASI } \rightarrow \\
\text { KEPUASAN } \\
\text { KERJA }\end{array}$ & $\begin{array}{l}H_{\infty}: \beta 1=0 \\
H_{13:} \beta_{1} \neq 0\end{array}$ & Ho ditolak & Dirrect effect & $\begin{array}{l}\text { Terdapat pengaruh } \\
\text { secara langsung } \\
\text { motivasi terhadap } \\
\text { kepuasan kerja } \\
\text { pegawai pada } \\
\text { Kantor Pelayanan } \\
\text { Pajak Pratama Solok }\end{array}$ \\
\hline 4 & $\begin{array}{l}\text { KEPUASAN } \\
\text { KERJA } \rightarrow \\
\text { KINERJA }\end{array}$ & $\begin{array}{l}H_{0 x}: \beta_{2}=0 \\
H_{14}: \beta_{2} \neq 0\end{array}$ & Ho ditolak & Dirrect effect & $\begin{array}{l}\text { Terdapat pengaruh } \\
\text { secara langsung } \\
\text { kepuasan kerja } \\
\text { terhadap kinerja } \\
\text { pegawai pada } \\
\text { Kantor Pelayanan } \\
\text { Pajak Pratama Solok }\end{array}$ \\
\hline 5 & $\begin{array}{l}\text { MOTIVASI } \rightarrow \\
\text { KINERJA }\end{array}$ & $\mathrm{H}_{0 s:} \beta_{3}=0$ & Ho ditolak & Dirrect effect & $\begin{array}{l}\text { Terdapat pengaruh } \\
\text { gecara langsung } \\
\text { motivasi terhadap } \\
\text { kinerja pegawai } \\
\text { pada Kantor } \\
\text { Pelayanan Pajak } \\
\text { Pratama Solok }\end{array}$ \\
\hline 6 & $\begin{array}{l}\text { BUDAYA } \\
\text { ORGANISASI } \rightarrow \\
\text { KINERJA }\end{array}$ & $H \propto x: y=0$ & Ho ditolak & Indirrect affect & $\begin{array}{l}\text { Terdapat pengaruh } \\
\text { gecara tidak } \\
\text { langgang budaya } \\
\text { organisasi terhadap } \\
\text { kinerja yang } \\
\text { dimediasi oleh } \\
\text { kepuasan kerja } \\
\text { pegawai pada } \\
\text { Kantor Pelayanan } \\
\text { Pajak Pratama Solok }\end{array}$ \\
\hline
\end{tabular}

Berdasarkan hasil perhitungan analisa secara keseluruhan baik analisis secara deskriptif ataupun pengujian hipotesis maka akan dijelaskan sebagai berikut: 
1. Kondisi Umum Kuat Lemah Budaya Organisasi, Tingkat Motivasi, Tingkat Kepuasan Kerja, serta Tingkat Kinerja Pegawai di Kantor Pelayanan Pajak Pratama Kota Solok

Hasil penelitian yang dilakukan menunjukan bahwa kuat lemah budaya organisasi, tingkat motivasi, tingkat kepuasan kerja serta tingkat kinerja pegawai di Kantor Pelayanan Pajak Pratama Kota Solok telah dinilai cukup baik oleh para responden namun masih harus lebih ditingkatkan karena semua skor yang diporoleh oleh setiap variabel berada di bawah skor ideal.

Pada variabel budaya organisasi skor total yang diperoleh cukup baik yakni termasuk ke dalam kategori tinggi sebesar 3325 atau sebesar $69.27 \%$ dari skor ideal 4800 , skor tertinggi diperoleh indikator inovasi dan pengambilan resiko yaitu $19.07 \%$, sedangkan skor total terendah pada indikator stabilitas yakni sebesar $8.27 \%$.

Pada variabel motivasi skor total yang diperoleh cukup baik yakni termasuk ke dalam kategori tinggi sebesar 2545 atau sebesar 79.531\% dari skor ideal 3200 , skor tertinggi diperoleh indikator prestasi yaitu $37.80 \%$, sedangkan skor total terendah pada indikator kekuasaan yakni sebesar $25.11 \%$. Pada penelitian ini di peroleh hasil bahwa indikator prestasi dinilai sangat baik oleh para responden, yakni sebesar $37.80 \%$, motivasi berupa dukungan dalam hal prestasi kerja pada kenyataanya memang sangatlah baik diterima oleh para pegawai Kantor Pelayanan Pajak Pratama Kota Solok bahkan bukan hanyak itu melainkan oleh seluruh pegawai Direktorat Jendral Pajak dibawah Kementrian Keuangan Republik Indonesia.

Pada variabel kepuasan kerja skor total yang diperoleh cukup baik yakni termasuk ke dalam kategori cukup sebesar 2628 atau sebesar $65.70 \%$ dari skor ideal 4000 , skor tertinggi diperoleh indikator sistem administrasi dan kebijakan yaitu $31.43 \%$, sedangkan skor total terendah pada indikator kondisi kerja yakni sebesar $21.77 \%$.

Pada variabel kepuasan kerja skor total yang diperoleh cukup baik yakni termasuk ke dalam kategori cukup sebesar 2628 atau sebesar $65.70 \%$ dari skor ideal 4000 , skor tertinggi diperoleh indikator sistem administrasi dan kebijakan yaitu $31.43 \%$, sedangkan skor total terendah pada indikator kondisi kerja yakni sebesar $21.77 \%$.

\section{Pengaruh Kuat Lemah Budaya Organisasi Terhadap Tingkat Motivasi Kerja Pegawai pada Kantor Pelayanan Pajak Pratama Solok}

Berdasarkan hasil rekapitulasi perhitungan skor mengenai tanggapan responden di Kantor Pelayanan Pajak Pratama Kota Solok untuk setiap indikator variabel budaya organisasi maka total skor terendah adalah indikator stabilitas dengan skor 275 dan total tertinggi adalah indikator inovasi dan pengambilan resiko yakni dengan skor 634. Total skor keseluruhan yang diperoleh pada semua indikator variabel budaya organisasi adalah 3325 dengan presentase sebesar $69.27 \%$ dari skor ideal yakni sebesar 4800 . Skor yang diperoleh tersebut menandakan bahwa kuat lemah budaya organisasi yang ada termasuk kategori tinggi.

Sedangkan untuk variabel motivasi kerja berdasarkan hasil rekapitulasi perhitungan skor mengenai tanggapan responden di Kantor Pelayanan Pajak Pratama Kota Solok skor tertinggi diperoleh indikator prestasi yaitu 962 atau $37.80 \%$ dari total semua indikator, sedangkan skor total terendah pada indikator kekuasaan yakni sebesar 639 atau 25.11\% dari total semua indikator. Pada variabel motivasi skor total yang diperoleh cukup baik yakni termasuk ke dalam kategori tinggi sebesar 2545 atau sebesar 79.531\% dari skor ideal 3200.

\section{Pengaruh Kuat Lemah Budaya Organisasi Terhadap Tingkat Kepuasan Kerja Pegawai pada Kantor Pelayanan Pajak Pratama Solok \\ Pada variabel kepuasan kerja skor total yang} diperoleh cukup baik yakni termasuk ke dalam kategori sedang sebesar 2628 atau sebesar $65.70 \%$ dari skor ideal 4000, skor tertinggi diperoleh indikator sistem administrasi dan kebijakan yaitu 826 atau $31.43 \%$ dari skor total semua indikator, sedangkan skor total terendah pada indikator kondisi kerja yakni sebesar 572 atau $21.77 \%$ dari skor total semua indikator.

Sedangkan pada variabel budaya organisasi total skor terendah adalah indikator stabilitas dengan skor 275 dan total tertinggi adalah indikator inovasi dan pengambilan resiko yakni dengan skor 634. Total 
skor keseluruhan yang diperoleh pada semua indikator variabel budaya organisasi adalah 3325 dengan presentase sebesar $69.27 \%$ dari skor ideal yakni sebesar 4800. Skor yang diperoleh tersebut menandakan bahwa kuat lemah budaya organisasi yang ada termasuk kategori tinggi.

\section{Pengaruh Tingkat Motivasi Kerja Terhadap Tingkat Kepuasan Kerja Pegawai pada Kantor Pelayanan Pajak Pratama Solok \\ Pada penelitian ini variabel motivasi kerja} berdasarkan hasil rekapitulasi perhitungan skor mengenai tanggapan responden di Kantor Pelayanan Pajak Pratama Kota Solok skor tertinggi diperoleh indikator prestasi yaitu 962 atau 37.80 \% dari total semua indikator, sedangkan skor total terendah pada indikator kekuasaan yakni sebesar 639 atau 25.11\% dari total semua indikator. Pada variabel motivasi skor total yang diperoleh cukup baik yakni termasuk ke dalam kategori tinggi sebesar 2545 atau sebesar 79.531\% dari skor ideal 3200.

Sedangkan pada variabel kepuasan kerja skor total yang diperoleh cukup baik yakni termasuk ke dalam kategori sedang sebesar 2628 atau sebesar 65.70\% dari skor ideal 4000 akan tetapi dikarenakan skor tersebut masih berada di bawah skor ideal maka harus dilakukan perbaikan. Skor tertinggi diperoleh indikator sistem administrasi dan kebijakan yaitu 826 atau $31.43 \%$ dari skor total semua indikator, sedangkan skor total terendah pada indikator kondisi kerja yakni sebesar 572 atau $21.77 \%$ dari skor total semua indikator.

\section{Pengaruh Tingkat Kepuasan Kerja Terhadap Tingkat Kinerja Pegawai pada Kantor Pelayanan Pajak Pratama Solok}

Pada penelitian ini pada variabel kepuasan kerja skor total yang diperoleh cukup baik yakni termasuk ke dalam kategori sedang sebesar 2628 atau sebesar $65.70 \%$ dari skor ideal 4000, skor tertinggi diperoleh indikator sistem administrasi dan kebijakan yaitu 826 atau $31.43 \%$ dari skor total semua indikator, sedangkan skor total terendah pada indikator kondisi kerja yakni sebesar 572 atau 21.77\% dari skor total semua indikator.

Sedangkan pada variabel kinerja skor total yang diperoleh cukup baik yakni termasuk ke dalam kategori cukup sebesar 2361 atau sebesar 59.025\% dari skor ideal 4000 , skor tertinggi diperoleh indikator efektifitas yaitu 516 atau $21.86 \%$ dari total skor pada semua indikator, sedangkan skor total terendah pada indikator kuantitas yakni sebesar 420 atau $17.79 \%$ dari total skor pada semua indikator.

\section{Pengaruh Tingkat Motivasi Kerja Terhadap Tingkat Kinerja Pegawai pada Kantor Pelayanan Pajak Pratama Solok}

Pada penelitian ini variabel motivasi kerja berdasarkan hasil rekapitulasi perhitungan skor mengenai tanggapan responden di Kantor Pelayanan Pajak Pratama Kota Solok skor tertinggi diperoleh indikator prestasi yaitu 962 atau 37.80 \% dari total semua indikator, sedangkan skor total terendah pada indikator kekuasaan yakni sebesar 639 atau 25.11\% dari total semua indikator. Pada variabel motivasi skor total yang diperoleh cukup baik yakni termasuk ke dalam kategori tinggi sebesar 2545 atau sebesar 79.531\% dari skor ideal 3200.

Sedangkan pada variabel kinerja skor total yang diperoleh cukup baik yakni termasuk ke dalam kategori cukup sebesar 2361 atau sebesar 59.025\% dari skor ideal 4000 , skor tertinggi diperoleh indikator efektifitas yaitu 516 atau $21.86 \%$ dari total skor pada semua indikator, sedangkan skor total terendah pada indikator kuantitas yakni sebesar 420 atau $17.79 \%$ dari total skor pada semua indikator.

\section{Pengaruh Kuat Lemah Budaya Organisasi Terhadap Tingkat Kinerja Pegawai pada Kantor Pelayanan Pajak Pratama Solok}

Berdasarkan hasil rekapitulasi perhitungan skor mengenai tanggapan responden di Kantor Pelayanan Pajak Pratama Kota Solok untuk setiap indikator variabel budaya organisasi maka total skor terendah adalah indikator stabilitas dengan skor 275 dan total tertinggi adalah indikator inovasi dan pengambilan 
resiko yakni dengan skor 634. Total skor keseluruhan yang diperoleh pada semua indikator variabel budaya organisasi adalah 3325 dengan presentase sebesar $69.27 \%$ dari skor ideal yakni sebesar 4800 . Skor yang diperoleh tersebut menandakan bahwa kuat lemah budaya organisasi yang ada termasuk kategori tinggi.

Sedangkan pada variabel kinerja skor total yang diperoleh cukup baik yakni termasuk ke dalam kategori cukup sebesar 2361 atau sebesar 59.025\% dari skor ideal 4000 , skor tertinggi diperoleh indikator efektifitas yaitu 516 atau $21.86 \%$ dari total skor pada semua indikator, sedangkan skor total terendah pada indikator kuantitas yakni sebesar 420 atau $17.79 \%$ dari total skor pada semua indikator.

\section{KESIMPULAN}

Tingkat budaya organisasi di Kantor Pelayanan Pajak Pratama di Kota Solok termasuk dalam kategori kuat serta tingkat motivasi kerja pegawai Kantor Pelayanan Pajak Pratama di Kota Solok termasuk dalam kategori tinggi sedangkan tingkat kepuasan kerja serta tingkat kinerja pegawai Kantor Pelayanan Pajak Pratama di Kota Solok termasuk dalam kategori sedang.

Budaya organisasi berpengaruh secara langsung dan positif terhadap motivasi kerja. Hal tersebut menunjukan bahwa semakin kuat budaya organisasi maka semakin tinggi tingkat motivasi kerja pegawai Kantor Pelayanan Pajak Pratama Kota Solok, begitu pula sebaliknya apabila semakin lemah budaya organisasi maka semakin rendah tingkat motivasi kerja pegawai Kantor Pelayanan Pajak Pratama Kota Solok.

Budaya organisasi berpengaruh secara langsung dan positif maupun secara tidak langsung melalui variabel motivasi kerja pegawai Kantor Pelayanan Pajak Pratama Kota Solok. Hal tersebut menunjukan bahwa semakin kuat budaya organisasi maka semakin tinggi tingkat kepuasan kerja pegawai Kantor Pelayanan Pajak Pratama Kota Solok. Disamping itu kepuasan kerja pegawai Kantor Pelayanan Pajak Pratama Kota Solok selain dipengaruhi oleh variabel budaya organisasi juga akan lebih baik bila didukung dengan peningkatan motivasi kerja.
Motivasi berpengaruh secara langsung dan positif terhadap kepuasan kerja. Hal tersebut menunjukan bahwa semakin tinggi tingkat motivasi kerja pegawai maka semakin tinggi tingkat kepuasan kerja pegawai Kantor Pelayanan Pajak Pratama Kota Solok.

Kepuasan kerja berpengaruh secara langsung dan positif terhadap kinerja. Hal tersebut menunjukan bahwa semakin tinggi tingkat kepuasan kerja pegawai maka semakin tinggi tingkat kinerja pegawai Kantor Pelayanan Pajak Pratama Kota Solok.

Motivasi kerja berpengaruh secara langsung dan positif terhadap kinerja. Hal tersebut menunjukan bahwa semakin tinggi tingkat motivasi kerja pegawai maka semakin tinggi tingkat kinerja pegawai Kantor Pelayanan Pajak Pratama Kota Solok.

Budaya organisasi tidak berpengaruh secara langsung terhadap kinerja tetapi berpengaruh secara tidak langsung melalui variabel kepuasan kerja. Hal tersebut menunjukan bahwa semakin kuat budaya organisasi yang diikuti dengan tingginya kepuasan kerja akan mengakibatkan semakin tinggi tingkat kinerja pegawai Kantor Pelayanan Pajak Pratama Kota Solok.

\section{REKOMENDASI}

Upaya peningkatan budaya organisasi dapat dilakukan dengan cara melakukan perumusan tujuan dengan jelas yang dapat mempermudah penentuan struktur dan fungsi organisasi, melakukan pembagian tugas dengan jelas sesuai dengan keahlian masingmasing pegawai, memiliki kejelasan struktur otoritas (kewenangan) karena tidak semua posisi memiliki kewenangan yang sama, dan pola hubungan informal.

Upaya peningkatan motivasi dapat dilakukan dengan cara lebih jelasnya struktur otoritas (kewenangan) karena tidak semua posisi memiliki kewenangan yang sama.

Kondisi kerja bukan hanya mengenai kondisi fisik akan tetapi juga kondisi psikologis dari lingkungan kerja. Oleh karena itu pimpinan Kantor Pelayanan Pajak Pratama Kota Solok harus dapat mengidentifikasi kondisi kerja seperti apa yang diinginkan oleh para pegawai guna menciptakan kondisi kerja yang kondusif dan nyaman. 
Upaya peningkatan kinerja dapat dilakukan dengan cara instensifikasi(peningkatan produktifitas dan cara kerja), ekstensifikasi(pencarian calon - calon wajib pajak baru) serta rasionalisasi (menggunakan teknologi - teknologi terbaru yang dapat mendukung) dan juga komputerisasi.

\section{DAFTAR PUSTAKA}

Abdillah, Willy dan Jogiyanto. (2015). Partial Least Square (PLS) Alternatif Structural Equation Modeling (SEM) dalam Penelitian Bisnis. Yogyakarta: Andi

Barker,Chris.,Pistrang,Nancy.,\& Elliot,Robert. (2002). Reasearch Methods In Clinical Psychology (2th ed) . Jhon Wiley \& Sons.

Dessler, Gary (2001) Manajemen Personalia Teknik dan Konsep Modern. Edisi Ketiga. Jakarta: Erlangga

Dharma, Surya. (2013). Manajemen Kinerja. Yogyakarta : Pustaka Pelajar:.

Garson, David G. (2012). Hierarchical Linear Modeling. Nort Carolina State University: SAGE Publications, Inc

Hair JF,Hult GTM,Ringle CM,Sarstedt M. (2014). A Primer on Partial Least Squares Structural Equation Modeling (PLS-SEM). Los Angeles: Sage. Handoko,T.Hani. (2008). Manajemen Personalia Sumber Daya Manusia. (edisi kedua). Yogyakarta: BPFE.

Hasibuan, Malayu. S.P. (2008). Manajemen Sumber Daya Manusia. Jakarta: PT Bumi Aksara

Hasibuan, Malayu. S.P. (2016). Manajemen Sumber Daya Manusia. (edisi revisi) Jakarta: PT Bumi Aksara

Hermawan, Asep. (2009). Penelitian Bisnis. Jakarta : PT. Grasindo

Husein Umar. (2009). Metode Penelitian untuk Skripsi Dan Tesis Bisnis, (edisi kedua). Jakarta : Rajagrafindo Persada.

Gima, Sugima. (2013) Metode Riset Bisnis dan Manajemen. Bandung: Intimarta

Greenberg,J dan Baron,RA. (2003). Behavior in Organization, Understanding and Managing The
Human Side of work. (edisi ketiga). Massachuscets: Alin and Bacon

Kotter,JP dan J.L.Heskett. (1997) Corporate Culture and Performance. Jakarta:PT Prenhalindo

Luthans,Fred. (2006). Perilaku Organisasi.(edisi 10 terjemahan Bahasa Indonesia). Yogyakarta: Penerbit Andi

Malhotra, Naresh K. (2010). Marketing Reseach : An Applied Orientation Sixth Edition. Pearson Education

Mangkunegara,AA. Anwar Prabu. (2010). Evaluasi Kinerja Sumber Daya Manusia. Bandung: PT. Refika Aditama.

Mangkuprawira, S., dan A.V. Hubeis, (2007) Manajemen Mutu Sumber Daya Manusia. .Bogor: Ghalia Indonesia

Mathis, Robert dan John Jackson. (2006). Human Resource Management (edisi ke sepuluh terjemahan)

Moekijat.(2003). Manajemen Kepegawaian. Jakarta : Penerbit Bumi Aksara.

Pabundu, Tika Moh. (2006). Budaya Organisasi dan Peningkatan Kinerja Perusahaan. Jakarta: PT Bumi Aksara.

Riduwan.(2005). Skala Pengukuran Variabel-Variabel Penelitian. Bandung: Alfabeta

Robbins, Stephen P. (2006). Perilaku Organisasi. Edisi kesepuluh. Jakarta: PT Indeks Kelompok Gramedia Robbins,Stephen P dan Timothy A. Judge. (2015). Perilaku Organisasi, (edisier 16). Jakarta: Salemba Empat

Sarwono, J., \& Narimawati, U. (2015). Membuat Skripsi, Tesis, dan Disertasi dengan Partial Least Square SEM (PLSSEM). Yogyakarta: Penerbit ANDI.

Siswanto (2002). Manajemen Kinerja.Jakarta: Gramedia Pustaka Utama.

Sedarmayanti, (2004). Pengembangan Kepribadian Pegawai.. Bandung: Penerbit Mandar Maju

Sekaran, Uma dan Bougie, Roger. (2013). Research Methods for Business. United Kingdom: Jhon Wiley \& Sons Ltd.

Sugiyono. (2010). Metode Penelitian Kuantitatif Kualitatif \& RND.Bandung: Alfabeta 
Sutrisno,Edy. (2011). Manajemen Sumber Daya Manusia. Jakarta : Kencana

Mangkunegara,AA. Anwar Prabu. (2010). Evaluasi Kinerja Sumber Daya Manusia. Bandung: PT. Refika Aditama.

Robbins,Stephen P dan Timothy A. Judge. (2015). Perilaku Organisasi, (edisier 16). Jakarta: Salemba Empat

Hasibuan, Malayu. S.P. (2016). Manajemen Sumber Daya Manusia. (edisi revisi) Jakarta: PT Bumi Aksara

Sugiyono. (2010). Metode Penelitian Kuantitatif Kualitatif \& RND. Bandung: Alfabeta 